\title{
COMMENT
}

\section{Reply to the comment of P. Kähler}

\author{
Paul E. Kepkay* \\ Biological Oceanography Section, Ocean Sciences Division, Bedford Institute of Oceanography, PO Box 1006, Dartmouth, \\ Nova Scotia, Canada B2Y 4A2
}

Following on from Dr Kähler's view of what may or may not make sense, I will briefly put the paper by Kepkay et al. (1997a) in the overall context of the 1995 bloom in Bedford Basin, and then go on to deal only with substantive comments.

Main characteristics of the bloom. Three papers were published on the 1995 spring bloom, dealing with respiration and the size fractionated $\mathrm{C}: \mathrm{N}$ ratio (Kepkay et al. 1997a), the relationship between specific size fractions of dissolved organic carbon (DOC) and diatom speciation (Kepkay et al. 1997b), and the role of transparent exopolymer particles (TEP) in the scavenging and sedimentation of organic carbon and ${ }^{234} \mathrm{Th}$ (Niven et al, 1997). Taken as a whole, the data indicate: (1) The production of organic carbon during the bloom was primarily in the dissolved $(<0.2 \mu \mathrm{m})$ size fraction. (2) The production of low molecular weight organic carbon (LOC) and colloidal organic carbon (COC) was related to the growth and succession of predominant diatom species, i.e. Skeletonema costatum at the beginning of the bloom and Chaetoceros socialis towards the end. (3) The concentration of COC and the rate of community oxygen consumption (respiration) were closely associated and, given the absence of any overall increase or decrease in dissolved organic nitrogen (DON) and particulate organic nitrogen (PON) during the course of the bloom, respiration was also associated with the $C: N$ ratio of colloidal organic matter (COM) and total organic matter (TOM). (4) The production of TEP was associated with the production of COC. In addition, the close association of TEP particles with the scavenging of ${ }^{234} \mathrm{Th}$ from the water column suggests that TEP was involved in the sedimentation of particulate organic matter collected by traps.

Measurement of DON. The high temperature catalytic oxidation (HTCO) method of Chen \& Wangersky

•E-mail: p_kepkay@bionet.bio.dfo.ca
(1993) was tested and blanked for both DOC and DON analysis, and the data submitted to a multi-analyst intercalibration. To date, only the DOC measurements have been reported (Sharp 1997). Nevertheless, the HTCO technique met or exceeded all of the analytical criteria established for the intercalibrations, and the results have been reported in detail by Chen (1992). With regards to Dr Kähler's comment on the 'validity' of the DON measurements, Kepkay et al. (1997a) have already pointed out that their results were in agreement with data from a number of authors, extending back to the work of Duursma (1961).

Analytical errors and mass balances. Dr Kähler is correct in his statement that COC and CON calculated by difference were less than the gross analytical errors at many of the sampling intervals. Only during the bloom were there easily discernible differences between dissolved and low molecular weight fractions. This general characteristic of blooms in Bedford Basin was originally reported by Kepkay et al. (1993).

Dr Kähler is also correct in suggesting that this 'does not necessarily mean that these measurements are bad', but then goes on to state that analytical precision and error propagation are overriding issues. This statement is only partially true. The critical operation in the size-separation of colloids by ultrafiltration is the determination of accurate mass balances by comparing concentrations calculated by difference to concentrations measured in the retentate (Buesseler et al. 1996, and references therein). Niven et al. (1997) found that the analytical errors for COC in retentates were small compared to the high carbon values produced by the 55- to 86-fold concentration of colloids during ultrafiltration. Added to this, the mass balances for CON were all greater than 95\% (Kepkay et al. 1997a); the mass balances for COC were greater than $98 \%$, except on Day 81 , when surface active organic carbon was found to be part of the colloid size fraction (Kepkay et al. $1997 \mathrm{bj}$. When mass balances of close to $100 \%$ are com- 
bined with the 55- to 86-fold concentration of COC and CON during ultrafiltration, minimal differences between the dissolved and low molecular weight fractions can be interpreted with greater confidence than Dr Kähler has suggested.

Calculation of C:N ratios. Dr Kähler has found 2 typographical errors in Table 1 that were transferred to the final manuscript submitted to the journal. When corrected, TOC at $15 \mathrm{~m}$ on Day 74 was $94.0 \mu \mathrm{MC}$ and on Day 81 was $89.3 \mu \mathrm{M} \mathrm{C}$ in Table 1. More serious errors were generated in Table 2 by a programming error (related to the fact that a spreadsheet macro was not adjusted for the absence of DON measurements at 2 of the sample intervals\}. The data in Figs. $4 \& 6$ are correct, and a corrected Table 2 is appended to this reply. The original observations that DON remained low and exhibited no overall variation during the bloom are confirmed in the corrected table. In addition, when combined with the fact that mass balances for the ultrafiltration of DON were all greater than $95 \%$, the corrected data reinforce the finding that, during this particular diatom bloom, there was very little organic nitrogen in the colloidal size fraction. I thank Dr Kähler for pointing out the errors and have learned a valuable lesson in the utilization of spreadsheet macros. As far as Figs. $2 \& 3$ are concerned, I cannot find the discrepancies in the data that are inferred from the plots.

Respiration and bacterial number. I agree with Dr Kähler that the correlation of respiration with the C:N of colloidal material cannot be used, by itself, to infer that bacteria were respiring colloids. However, the results from earlier work (Kepkay \& Johnson 1989, review by Kepkay 1994) suggest that elevated respiration in both Bedford Basin and the open ocean was associated with elevated bacterial numbers after the aggregation of colloid-sized fractions of DOC. Cells that were larger than bacteria also increased in number after aggregation, but these cells could not be identified unequivocally as microflagellates. Given this limitation, Kepkay et al. (1997a) referred to the earlier work and acknowledged that the complete microbial community (rather than just the bacteria) could be involved in the respiration of colloids. Dr Kähler's own 'stepwise verbal transformation' of phrases taken from unrelated paragraphs (culminating in the declaration of '...Bingo!') serves no purpose and adds nothing to this discussion

Organic carbon budget. As far as establishing an organic carbon budget for the 1995 bloom is concerned, the main issue is that the rapid and short-lived sedimentation of organic matter at the beginning and towards the end of the bloom (Niven et al. 1997) was sampled over a completely different time interval than the once-a-week measurements of respiration. Added to this is the possibility that TEP associated with colloid production during the bloom can settle out rapidly as aggregates and remove organic carbon without removing chlorophyll from the upper water column. By itself, the mismatch of temporal scales during sampling indicates that it is certainly not possible to establish the effect of respiration on the bloom carbon budget with the data collected to date. It is also possible that nitrogen was cycled faster than the 1 wk sampling interval (Kepkay et al. 1997a). Even though this may seem to be an 'obscure novel pathway' to Dr Kähler, rapid recycling cannot be discounted and is certainly in agreement with the $1 \mathrm{~d}$ to $1 \mathrm{wk}$ response time of estuarine systems (Smith \& Mackenzie 1987).

Phytoplankton blooms in Bedford Basin-do they make sense? The purpose of repeating chlorophyll and respiration plots was to allow the reader to have direct visual comparison of parameters with easy reference to the progression of the bloom. If Dr Kähler thinks that this is an attempt 'to cover as much paper as possible with the least amount of data' then so be it.

Blooms in Bedford Basin have been monitored as far back as the early 1970s. One of the hallmarks of the data sets is that the timing and duration of the spring bloom are sensitive to a variety of parameters, including phytoplankton speciation and discharge of the Sackville River. For example, when discharge was low during the spring of 1995, the hydrography of a poorly stratified, cold water bloom (Kepkay et al. 1997a) was completely different from the well-stratified 1992 bloom (Kepkay et al. 1993), when discharge was high. In addition, the predominant diatom species were Skeletonema costatum and Chaetoceros socialis in 1995, whereas only C. socialis was predominant in 1992. Very different distributions of DOC, COC and LOC were measured during the 2 blooms, which leads to the perhaps obvious statement that no one event is typical of Bedford Basin. In this sense, the strong variability of blooms from year to year is certainly at odds with Dr Kähler's statement that he 'cannot believe that a phytoplankton bloom is that hard to understand.'

With regards to data making 'sense' to Dr Kähler, the respiration values reported by Kepkay et al. (1997a) are well within the range reviewed and established by Smith \& Hollibaugh (1993). In addition, they were also measured over $11 \mathrm{wk}-\mathrm{a}$ considerably longer time period than most respiration studies that I know of. The C: $\mathrm{N}$ ratios of Kepkay et al. (1997a) are also in good agreement with the results obtained by Biddanda \& Benner (1997) from phytoplankton cultures and are in agreement with the range of values reported by authors extending back to Duursma (1961). Time will tell if these data, rather than Dr Kähler's comments, make sense. 
Corrected Table 2. TON, PON, DON, LON and CON concentrations during the pre-bloom, bloom (Days 74 to 102) and post-bloom at $15 \mathrm{~m}$. The precision of DON and LON measurements was $\leq 0.3 \mu \mathrm{MN}(1 \sigma)$ : the precision of PON measurements was $\leq 0.6 \mu \mathrm{M} \mathrm{N}(1 \sigma)$

\begin{tabular}{|c|c|c|c|c|c|}
\hline $\begin{array}{l}\text { Day of } \\
\text { year }\end{array}$ & $\begin{array}{l}\text { TON }^{d} \\
(\mu \mathrm{M})\end{array}$ & $\begin{array}{c}\text { PON } \\
(\mu \mathrm{M} N)\end{array}$ & $\begin{array}{l}\text { DON }^{b} \\
(\mu M N)\end{array}$ & $\begin{array}{c}\operatorname{LON}^{c} \\
(\mu M N)\end{array}$ & $\begin{array}{l}\mathrm{CON}^{\mathrm{d}} \\
(\mu \mathrm{MN})\end{array}$ \\
\hline $46^{\mathrm{e}}$ & 10.9 & 1.4 & 9.5 & 9.2 & 0.3 \\
\hline 53 & 12.1 & 2.6 & 9.5 & 9.2 & 0.3 \\
\hline 60 & 13.4 & 2.6 & 10.8 & 10.3 & 0.5 \\
\hline 74 & 14.5 & 2.1 & 12.4 & 11.8 & 0.6 \\
\hline 81 & 10.6 & 2.4 & 8.2 & 7.1 & 1.1 \\
\hline 88 & 15.2 & 4.7 & 10.5 & 9.4 & 1.1 \\
\hline 95 & 18.2 & 7.6 & 10.6 & 9.3 & 1.3 \\
\hline 109 & 16.2 & 4.6 & 11.6 & 10.5 & 1.1 \\
\hline 116 & 16.3 & 3.4 & 12.9 & 12.2 & 0.7 \\
\hline $123^{f}$ & 14.1 & 3.8 & 10.3 & 9.8 & 0.5 \\
\hline \multicolumn{6}{|c|}{$\begin{array}{l}{ }^{\text {a }} \text { Calculated as the sum of PON and DON } \\
\text { bOrganic nitrogen that passes through a pre-cleaned } \\
0.2 \mu \mathrm{m} \text { cartridge filter } \\
\text { c Organic nitrogen that passes through the membranes in } \\
\text { pre-cleaned cross-flow, ultra-filtration cartridges with a } \\
\text { nominal molecular weight cut-off of } 10000 \mathrm{Da}(1 \text { to } 2 \mathrm{~nm}) \\
{ }^{d} \text { Calculated as the difference between DON and LON } \\
\text { concentrations } \\
\text { e Feb 15, } 1995 \\
\text { f May 3,1995 }\end{array}$} \\
\hline
\end{tabular}

\section{LITERATURE CITED}

Biddanda B, Benner R (1997) Carbon, nitrogen and carbohydrate fluxes during the production of particulate and dissolved organic matter by marine phytoplankton. Lim. nol Oceanogr 42:506-518
Buesseler KO, Bauer JE, Chen RF, Eglinton TI, Gustafsson O, Landing W, Mopper K, Moran SB, Santschi PH, Vernon Clark R, Wells ML (1996) An intercomparison of crossflow filtration techniques used for sampling marine colloids: overview and organic carbon results. Mar Chem 55 $1-31$

Chen $W$ (1992) The measurement, production and degradation of marine dissolved organic matter. $\mathrm{PhD}$ thesis, Dalhousie University, Halifax

Chen W, Wangersky PJ (1993) A high temperature catalytic oxidation method for the determination of marine dissolved organic carbon and its comparison with the ultraviolet photo-oxidation method. Mar Chem 42:95-106

Duursma E (1961) Dissolved organic carbon, nitrogen and phosphorous in the sea. Neth J Sea Res 1:1-148

Kepkay PE (1994) Particle aggregation and the biological reactivity of colloids. Mar Ecol Prog Ser 109:293-304

Kepkay PE, Johnson BD (1989) Coagulation on bubbles allows the microbial respiration of oceanic dissolved organic carbon. Nature 385:63-65

Kepkay PE, Niven SEH, Milligan TG (1993) Low molecular weight and colloidal DOC production during a phytoplankton bloom. Mar Ecol Prog Ser 100:233-244

Kepkay P, Jellett JF, Niven SEH (1997a) Respiration and the carbon-to-nitrogen ratio of a phytoplankton bloom. Mar Ecol Prog Ser 150:249-261

Kepkay PE, Niven SEH, Jellett JF (1997b) Colloidal organic carbon and phytoplankton speciation during a coastal bloom. J Plankton Res 19:369-389

Niven SEH, Kepkay PE, Bugden JBC (1997) The role of TEP in ${ }^{234} \mathrm{Th}$ scavenging during a coastal diatom bloom. Radioprotection Colloques 32 C2:213-218

Sharp JH (1997) Marine dissolved organic carbon: are the older values correct? Mar Chem 56:265-277

Smith SV, MacKenzie FT (1987) The ocean as a net het erotrophic system: implications from the global biogeochemical cycle. Global Biogeochem Cycles 1:195-215

Smith SV, Hollibaugh JT (1993) Coastal metabolism and the oceanic carbon balance. Rev Geophys 31:75-89 